University of Nebraska - Lincoln

DigitalCommons@University of Nebraska - Lincoln

\title{
An experimental and kinetic modeling study of methyl formate low-pressure flames
}

\author{
S. Dooley \\ Princeton University, Princeton, NJ \\ F. L. Dryer \\ Princeton University, Princeton, NJ \\ B. Yang \\ Cornell University, Ithaca, NY \\ J. Wang \\ Cornell University, Ithaca, NY \\ T. A. Cool \\ Cornell University, Ithaca, NY \\ See next page for additional authors
}

Follow this and additional works at: https://digitalcommons.unl.edu/usdoepub

Part of the Bioresource and Agricultural Engineering Commons

Dooley, S.; Dryer, F. L.; Yang, B.; Wang, J.; Cool, T. A.; Kasper, T.; and Hansen, N., "An experimental and kinetic modeling study of methyl formate low-pressure flames" (2011). US Department of Energy Publications. 111.

https://digitalcommons.unl.edu/usdoepub/111

This Article is brought to you for free and open access by the U.S. Department of Energy at DigitalCommons@University of Nebraska - Lincoln. It has been accepted for inclusion in US Department of Energy Publications by an authorized administrator of DigitalCommons@University of Nebraska - Lincoln. 


\section{Authors}

S. Dooley, F. L. Dryer, B. Yang, J. Wang, T. A. Cool, T. Kasper, and N. Hansen 


\title{
An experimental and kinetic modeling study of methyl formate low-pressure flames
}

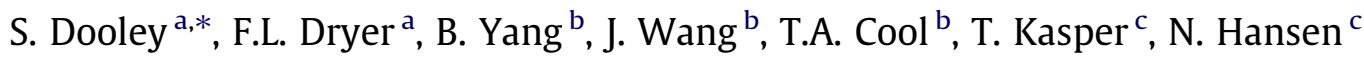 \\ a Department of Mechanical and Aerospace Engineering, Princeton University, Princeton, NJ 08544, USA \\ ${ }^{\mathrm{b}}$ School of Applied and Engineering Physics, Cornell University, Ithaca, NY 14853, USA \\ c Combustion Research Facility, Sandia National Laboratories, Livermore, CA 94551, USA
}

\section{A R T I C L E I N F O}

\section{Article history:}

Received 22 July 2010

Received in revised form 2 November 2010

Accepted 4 November 2010

Available online 2 December 2010

\section{Keywords:}

Methyl ester

Methyl formate

Kinetic model

Low-pressure flame

MBMS

\begin{abstract}
A B S T R A C T
The oxidation of methyl formate $\left(\mathrm{CH}_{3} \mathrm{OCHO}\right)$, the simplest methyl ester, is studied in a series of burnerstabilized laminar flames at pressures of 22-30 Torr and equivalence ratios $(\Phi)$ from 1.0 to 1.8 for flame conditions of $25-35 \%$ fuel. Flame structures are determined by quantitative measurements of species mole fractions with flame-sampling molecular-beam synchrotron photoionization mass spectrometry (PIMS). Methyl formate is observed to be converted to methanol, formaldehyde and methane as major intermediate species of mechanistic relevance. Smaller amounts of ethylene and acetylene are also formed from methyl formate oxidation. Reactant, product and major intermediate species profiles are in good agreement with the computations of a recently developed kinetic model for methyl formate oxidation [S. Dooley, M.P. Burke, M. Chaos, Y. Stein, F.L. Dryer, V.P. Zhukov, O. Finch, J.M. Simmie, H.J. Curran, Int. J. Chem. Kinet. 42 (2010) 527-529] which shows that hydrogen abstraction reactions dominate fuel consumption under the tested flame conditions. Radical-radical reactions are shown to be significant in the formation of a number of small concentration intermediates, including the production of ethyl formate $\left(\mathrm{C}_{2} \mathrm{H}_{5} \mathrm{OCHO}\right)$, the subsequent decomposition of which is the major source of observed ethylene concentrations. The good agreement of model computations with this set of experimental data provides a further test of the predictive capabilities of the proposed mechanism of methyl formate oxidation. Other salient issues in the development of this model are discussed, including recent controversy regarding the methyl formate decomposition mechanism, and uncertainties in the experimental measurement and modeling of low-pressure flame-sampling experiments. Kinetic model computations show that worst-case disturbances to the measured temperature field, which may be caused by the insertion of the sampling cone into the flame, do not alter mechanistic conclusions provided by the kinetic model. However, such perturbations are shown to be responsible for disparities in species location between measurement and computation.
\end{abstract}

(c) 2010 The Combustion Institute. Published by Elsevier Inc. All rights reserved.

\section{Introduction}

Methyl esters of varying alkyl chain length are the primary constituents of biodiesel. Methyl formate (MF), Fig. 1, represents the simplest methyl ester and as such its study allows for the isolation of the role of the ester functionality on combustion processes. Therefore it may be used as a test molecule for the development of more accurate methods for the estimation of rate constants and thermochemistry involved in the oxidation of oxygenates and hydrocarbons which have not been well characterized, particularly for other ester type species [1,2].

We have recently reported on the construction and validation of a detailed kinetic model for MF oxidation [3]. This model has been tested against: (a) flow reactor temporal speciation data measured during MF oxidation at $3 \mathrm{~atm}$ and $900 \mathrm{~K}$ at mixture compositions of

\footnotetext{
* Corresponding author.

E-mail address: dooleys@princeton.edu (S. Dooley).
}

$\Phi=0.5,1$ and 1.5 , and for pyrolysis at $950 \mathrm{~K}$, each using $0.5 \% \mathrm{MF}$ (b) shock tube ignition delay times measured at pressures of $\sim 2.7, \sim 5.4$ and $\sim 9.4$ atm at temperatures of $1275-1935 \mathrm{~K}$ for mixture compositions of $0.5 \%$ fuel at $\Phi=0.5 \%, 1.0 \%$ and $2.0 \%$ and $2.5 \%$ fuel at $\Phi=1.0$ (c) laminar burning velocities measured using atmospheric pressure outwardly propagating flames at equivalence ratios of $0.8-1.6$ in synthetic air.

The kinetic model successfully reproduces the experimental results. Analysis shows that the consumption of MF in the flow reactor and especially shock tube environments involves a concerted elimination reaction of fuel to form methanol and carbon<smiles>COC=O</smiles>

Fig. 1. Molecular structure of methyl formate. 
monoxide. In contrast, in outwardly propagating atmospheric pressure flames the kinetic model shows that the role of this reaction is lessened due to the comparatively radical rich nature which permits bimolecular hydrogen abstraction reactions to be the dominant mode of MF oxidation in that environment.

The estimation of accurate chemical kinetic and thermochemical parameters for the oxidation of oxygenates such as this basic ester is complicated by molecular structural and thermochemical effects due to influence of the ester functionality on surrounding atoms and bonds. The result is that the quantitative details of these oxidation processes are difficult to estimate or possibly even calculate accurately. Similar complications exist for other oxygenated functionalities such as ketones and furans. It is the aim of this study to improve our understanding of the mechanisms of oxygenate oxidation, such that methods for the estimation of rate constants and thermochemical parameters from such ill characterized systems can be tested and developed. These methods ought to be extendable to biodiesel and cellulosic (or recently reported valeric) biofuels where the oxygenated functionality may be present in diverse configurations [4].

In our previous modeling effort [3], the rate constants for MF decomposition were estimated from chemical group theory [5], the $A$-factor was reduced by a factor of five to be consistent with pyrolysis data from a flow reactor study. An apparent discrepancy between experiment and quantum chemical computation (by Francisco [6]) of the energy barrier to MF decomposition was also highlighted. If the computed values of Francisco [6] are employed in the kinetic model shock tube ignition delays show a much higher activation energy than observed in experiment, and flow reactor pyrolysis data cannot be reproduced. Subsequently, Metcalfe et al. [7] have computed pressure-dependent rate constants for MF decomposition with "ab initio" methods and have confirmed that the computations of Francisco may be in error. The direct measurement of methanol formation from MF oxidation in this study provides a further direct test of the various chemical kinetic descriptions of MF decomposition. Our previous MF modeling work relies on relating the $\mathrm{C}-\mathrm{H}$ bond dissociation energy to known rate constants for hydrogen abstraction reactions as a method for the estimation of kinetic modeling parameters. This methodology is herein further tested against the detailed measurement of the intermediate species involved in MF oxidation in flame environments.

\section{Experimental}

A flame-sampling photoionization mass spectrometer, employing tunable vacuum-ultraviolet synchrotron radiation, is used for these studies [8-10]. Detailed descriptions of the instrument and experimental procedures are given elsewhere [10-13]. This instrument consists of a low-pressure flame chamber, a differentially pumped molecular-beam flame-sampling system, and a linear time-of-flight mass spectrometer (TOFMS). It is coupled to a $3 \mathrm{~m}$ monochromator used to disperse synchrotron radiation at the Advanced Light Source of the Lawrence Berkeley National Laboratory. The monochromator delivers a dispersed photon beam, tunable over the range from 8 to $17 \mathrm{eV}$, with an energy resolution of $40 \mathrm{meV}$ (fwhm) for the present experiments and a typical photon current of $5 \times 10^{13}$ photons/s. A silicon photodiode, with its quantum efficiency (electrons/photon) calibrated at the National Institute of Standards and Technology (NIST), records the variation in photon current (photons/s) with photon energy and time.

Flame gases are sampled along the axis of a flat flame burner by a quartz cone of $0.3 \mathrm{~mm}$ orifice diameter. The burner can be moved toward or away from the sampling cone to make measurements at different distances within the flame. The molecular beam from the sampling system is crossed by the dispersed VUV light from the
Table 1

Experimental conditions of methyl formate flames, standard litres per minute $\left(\mathrm{slm}^{-1}\right)$, flow velocity at $300 \mathrm{~K}\left(\mathrm{v}_{300 \mathrm{~K}}\right)$.

\begin{tabular}{lllllll}
\hline$\Phi$ & $\mathrm{MF}^{2} / \mathrm{slm}^{-1}$ & $\mathrm{O}_{2} \% / \mathrm{slm}^{-1}$ & $\mathrm{Ar}^{2} / \mathrm{slm}^{-1}$ & $\mathrm{C} / \mathrm{O}$ & $p /$ Torr & $\mathrm{v}_{300 \kappa} / \mathrm{cm} \mathrm{s}^{-1}$ \\
\hline 1.0 & $25.2 / 1.02$ & $50.2 / 1.02$ & $24.6 / 1.0$ & 0.334 & 22 & 90.9 \\
1.2 & $28.3 / 1.15$ & $47.1 / 1.15$ & $24.6 / 1.0$ & 0.376 & 24 & 83.3 \\
1.4 & $31.1 / 1.26$ & $31.1 / 1.26$ & $24.6 / 1.0$ & 0.412 & 26 & 76.9 \\
1.6 & $33.5 / 1.36$ & $33.5 / 1.36$ & $24.6 / 1.0$ & 0.445 & 28 & 71.4 \\
1.8 & $35.8 / 1.45$ & $35.8 / 1.45$ & $24.6 / 1.0$ & 0.475 & 30 & 66.6 \\
\hline
\end{tabular}

monochromator, and photo-ions are collected and mass-analyzed with a TOFMS with a mass resolution of $m / \Delta m=500$. Two types of experiments are conducted. In the first mode, the photon energy is fixed while the burner position is systematically varied to produce mass spectra for individual species as a function of the distance from the burner. In a second mode of operation, the burnercone separation is fixed and species mass spectra are recorded as a function of photon energy with a resolution of $40 \mathrm{meV}$ (fwhm). The variation of ion signal as a function of photon energy yields a photoionization efficiency (PIE) spectrum for each ion mass. Although no example will be shown here, all the species reported in this paper have been identified by their PIE spectra. Five flames with equivalence ratios ranging from a $\Phi=1.0$ stoichiometric flame to a $\Phi=1.8$ fuel-rich flame, near the flat-flame stability limit, were studied at the conditions of Table 1 . The flame pressures are chosen to maximize spatial resolution while maintaining flame stability.

Methyl formate (99\%) is obtained from Sigma-Aldrich and used without further purification. Oxygen and argon are purchased from Matheson Tri-Gas at purities of $99.98 \%$ and $99.999 \%$ respectively. Flame temperatures for each of the five flames are measured using laser-induced fluorescence (LIF) from $\cdot \mathrm{OH}$ under flame conditions unperturbed by the sampling cone using the procedure described by McIlroy et al. [14]. The uncertainty of the temperature measurements is estimated to be $\pm 100 \mathrm{~K}$. The procedures used for determination of the major species profiles are described elsewhere [10-12]. The measured argon ion signal is used to deduce an empirical instrumental sampling function $F(k, T, P)$ that is used to relate the molecular beam molar density at the ionization region to the molar density within the flame at the flame temperature $(T)$ and pressure $(p)$, where $(k)$ is the specific heat ratio of the flame sample. This sampling function is used to relate ion signal measurements for a given flame species to its concentration profile throughout the flame. The absolute mole fractions of argon, carbon monoxide, carbon dioxide, water, and hydrogen are determined by atom balances in the post flame zone at a position $30 \mathrm{~mm}$ from the burner face. The balances rely on kinetic model calculated mole fractions for oxygen atom $(\cdot \mathrm{O})$, hydrogen atom $(\cdot \mathrm{H})$, and hydroxyl radical $(\cdot \mathrm{OH})$ as these species may not at present be accurately quantified with PIMS, and on a measurement of the ratio of $\mathrm{CO}$ to $\mathrm{CO}_{2}$ ion signals calibrated against ion signals measured for a cold flow mixture of $\mathrm{CO}$ and $\mathrm{CO}_{2}$ of known composition. The accuracies of the reported mole fractions are estimated to be within $20 \%$ for major species $\left(\mathrm{CO}, \mathrm{CO}_{2}, \mathrm{H}_{2} \mathrm{O}, \mathrm{H}_{2}, \mathrm{Ar}, \mathrm{O}_{2}\right.$, $\mathrm{MF}$ ), and the estimated error for intermediates range from $\pm 30 \%$ to $50 \%$ for intermediate species $\left(\mathrm{CH}_{2} \mathrm{O}, \mathrm{CH}_{4}, \mathrm{C}_{2} \mathrm{H}_{2}, \mathrm{C}_{2} \mathrm{H}_{4}, \mathrm{CH}_{3}, \mathrm{CH}_{3} \mathrm{OH}\right)$.

\section{Kinetic modeling}

The kinetic modeling computations reported in this study are performed using the PREMIX module of the CHEMKIN II package of programs [15]. The calculations employ the experimentally determined temperature profile for each individual flame (unless stated otherwise) and use one thousand grid points to allow for grid independent solutions. Multi-component transport and thermal diffusion are considered in the computations. A chemical kinetic model for MF oxidation [3] which we have recently devel- 
oped for high-pressure conditions is further tested against experimental data herein. This model employs the $C_{2}$ sub mechanism of Healy et al. [16].

In this paper "Distance from Burner" refers to the actual separation between the tip of the sampling cone and the burner face, with no correction for probe sampling effects. The modeling results are shifted away from the burner to better match the experimental profiles. The computed species profiles are adjusted by $0.5 \mathrm{~mm}$ for the $\Phi=1.2,1.4$, and 1.6 flames by $1.5 \mathrm{~mm}$ for the $\Phi=1.8$ flame. Data for the $\Phi=1.0$ flame are unadjusted. These uncertainties arise as a result of disturbances caused by the molecular beam sampling probe to the flow parameters slightly upstream of the sampling cone orifice $[17,18]$, and by observed slight changes in flame liftoff from the burner surface, particularly for the richest $\Phi=1.8$ flame. The modeling shifts are within uncertainties in both the measurement of burner-cone separations $(0.5 \mathrm{~mm})$ and in empirical estimates of the shifts $(1.0-1.5 \mathrm{~mm})$ needed to account for sampling effects for species profiles measured with the $0.3 \mathrm{~mm}$ aperture quartz probe [17]. This treatment is consistent with the recent analysis presented by Struckmeier et al. [19], who suggest uncertainties in reported burner distance of up to $\sim 1 \mathrm{~mm}$ for conditions very similar to the current study. We have decided to represent this error by $x$-axis offset to our modeling computations rather than by reporting error bars on the experimental data as the resulting figures are most unclear and not easily interpreted. The reader is made aware of the apparent uncertainty in distance from the burner in caption to Figs. 2-7.

\section{Results and discussion}

Experimental measurements and the results of the modeling computations are shown in Figs. 2 and 3, and are also compared to the data of Westbrook et al. [1], who studied a very similar $\Phi=1.83$ flame in Fig. 4. MF flames are observed to form large quantities of hydrogen $\left(\mathrm{H}_{2}\right)$, carbon monoxide $(\mathrm{CO})$ and water $\left(\mathrm{H}_{2} \mathrm{O}\right)$ in the reaction zone, with the usual conversion of carbon monoxide to carbon dioxide $\left(\mathrm{CO}_{2}\right)$ at larger distances from the burner. The expected increase in peak $\mathrm{CO}$ concentration and decrease in peak $\mathrm{CO}_{2}$ concentration as equivalence ratio is increased is also observed. Results of modeling computations are depicted in Figs. 2-4 as lines, and they reproduce the major species measured within the flames including fuel and oxidizer very well. Computed $\mathrm{H}_{2}$ profiles exhibit discrepancies as large as $30 \%$ for the $\Phi=1.4,1.6$ and 1.8 flames. The fidelity of computed and measured major species profiles is of relatively less interest to the present goal of achieving a quantitative mechanistic understanding of methyl ester/oxygenate oxidation. The evolution of these species is largely governed by very well known thermochemical inputs and hence depends largely on the experimentally
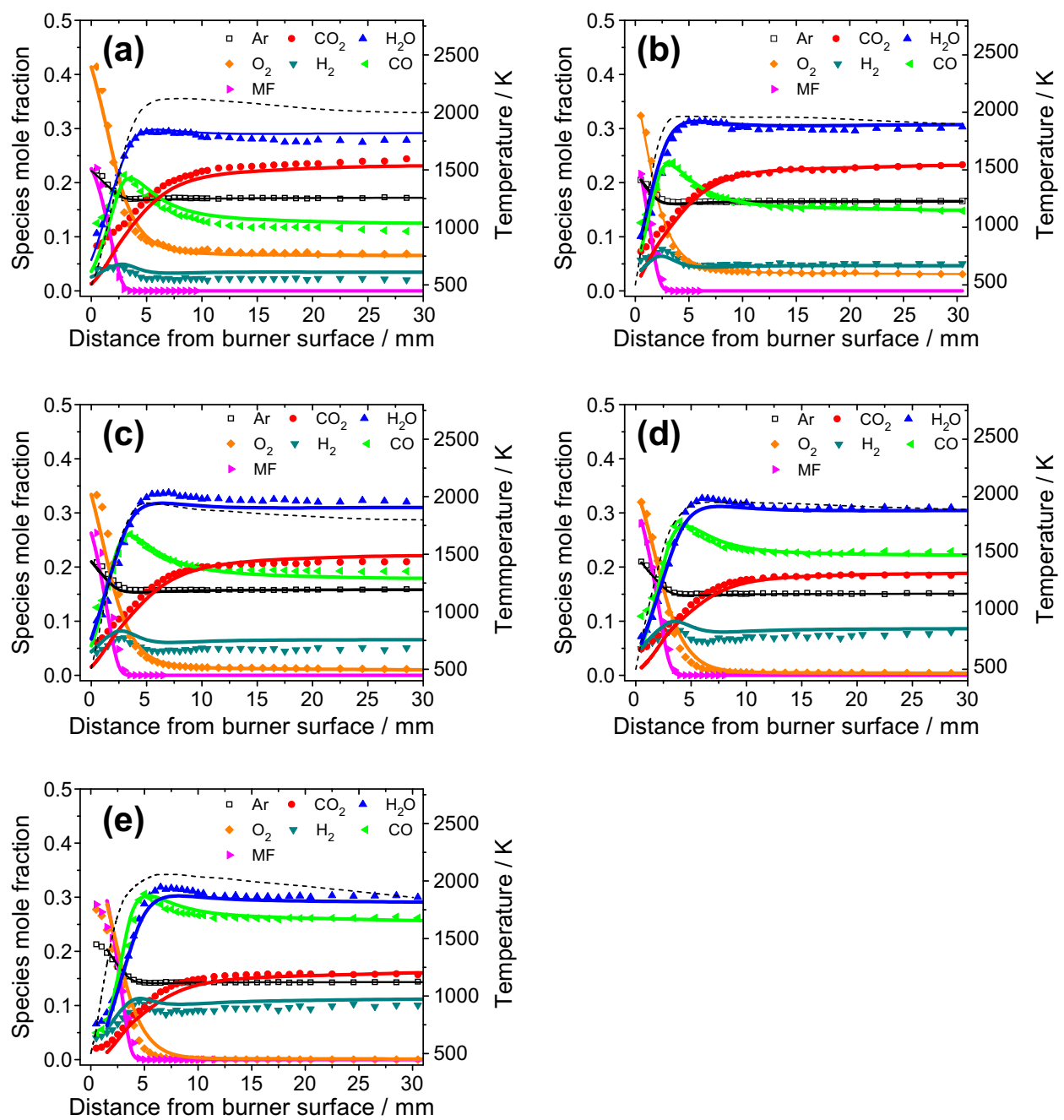

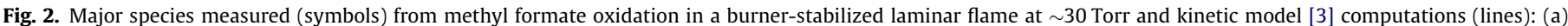

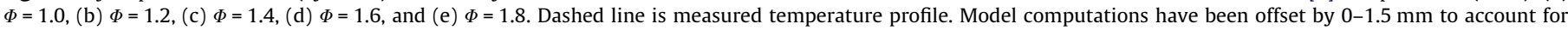
experimental uncertainties, see text. 

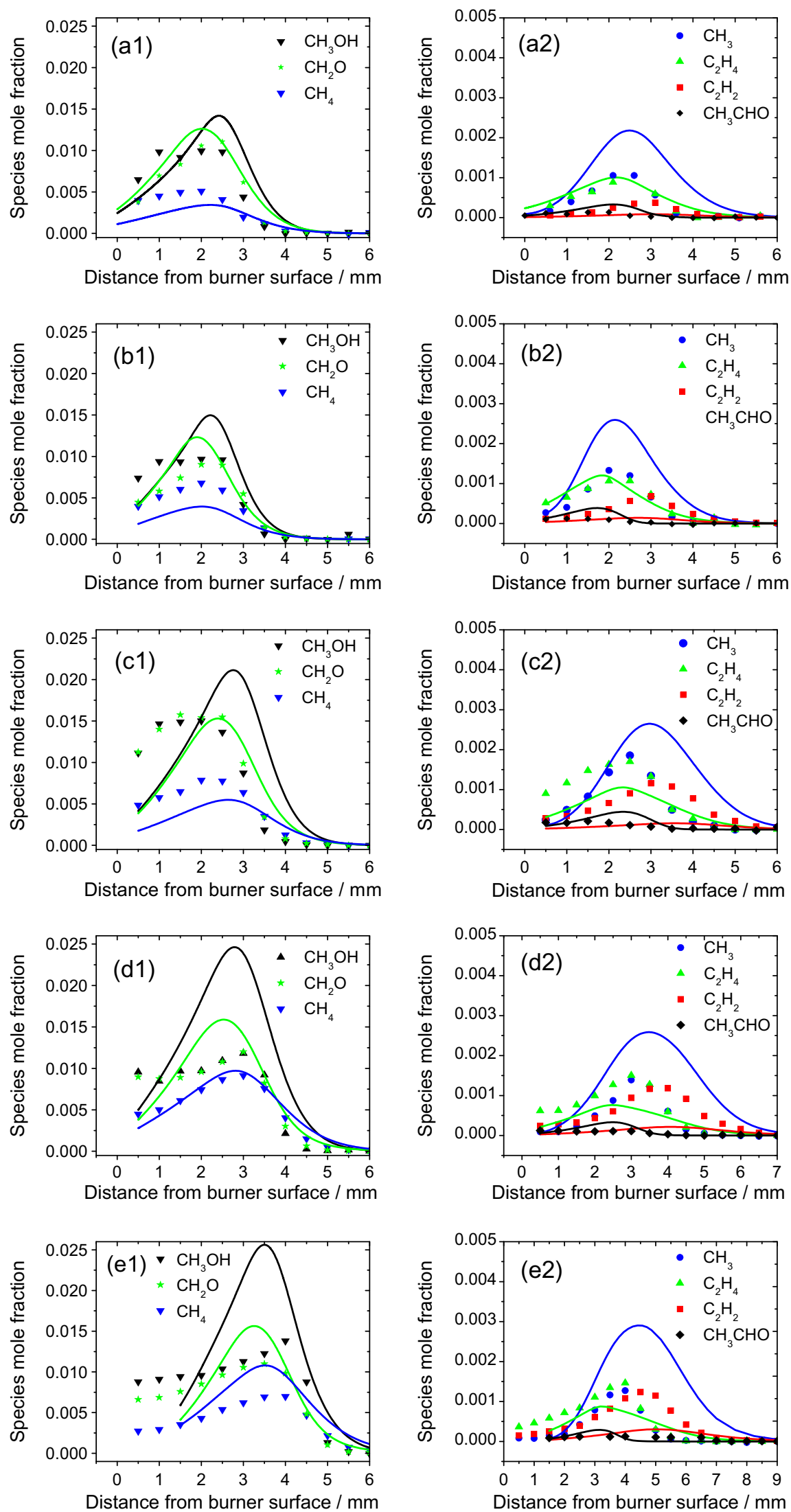

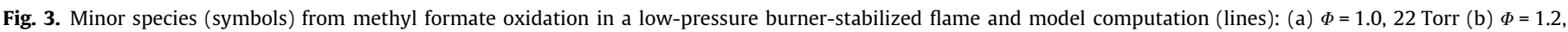

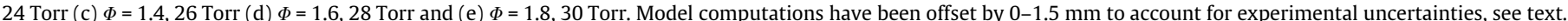

measured temperature profile of the flame that is employed as input to computations. Hence our detailed discussion will center on the intermediate species within the reaction zone that can provide the desired mechanistic insights. 

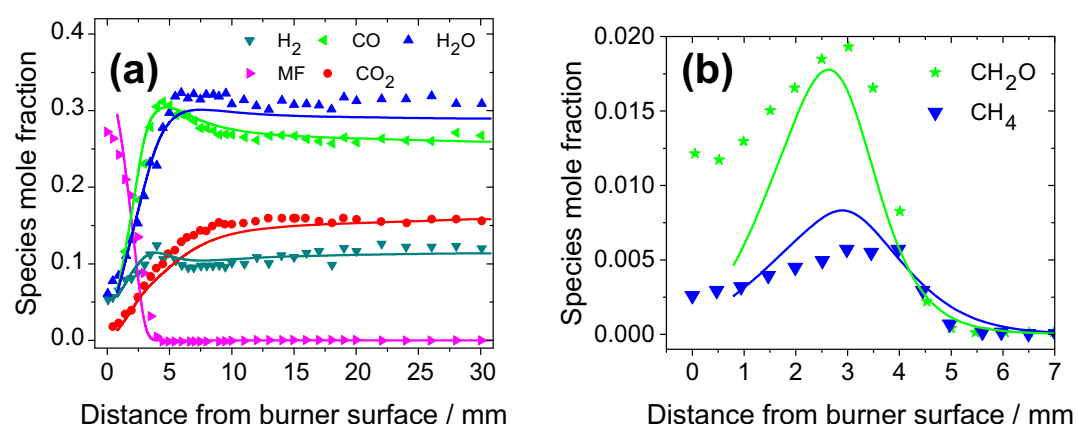

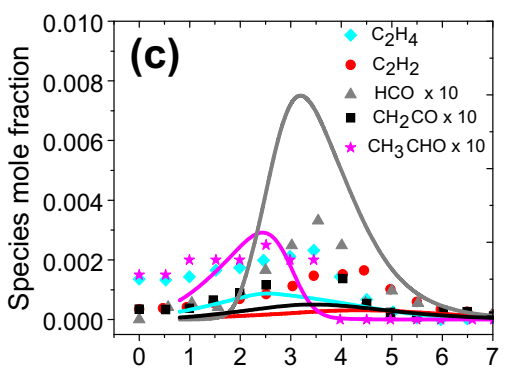

Distance from burner surface / $\mathrm{mm}$

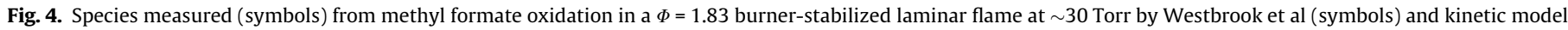
[3] computations (lines). Model computations have been offset by $1.0 \mathrm{~mm}$ to account for experimental uncertainties, see text.

Figure 3 shows the major intermediate species identified in the reaction zone $(0-7 \mathrm{~mm}$ from the burner surface). Methanol $\left(\mathrm{CH}_{3} \mathrm{OH}\right)$ and formaldehyde $\left(\mathrm{CH}_{2} \mathrm{O}\right)$ are the most prominent intermediates formed in the high-temperature flame oxidation of MF. This observation is consistent with previous speciation measurements at much lower temperature and higher pressure $(900 \mathrm{~K}$, $3 \mathrm{~atm}$ ) in a flow reactor, and also with the $\mathrm{CH}_{2} \mathrm{O}$ measurements of Westbrook et al. [1] which are very similar to those reported in this study. Methane $\left(\mathrm{CH}_{4}\right)$ and the methyl radical $\left(\mathrm{CH}_{3}\right)$ are also detected in significant quantities. Approximately one thousand parts per million ethylene $\left(\mathrm{C}_{2} \mathrm{H}_{4}\right)$ and acetylene $\left(\mathrm{C}_{2} \mathrm{H}_{2}\right)$ are also observed to be formed. Their detection is most interesting as the molecular structure of this ester fuel is void of carbon-to-carbon bonds, indicating that the formation of the $C_{2}$ species is due to some radical recombination process. Computations with our previously developed kinetic model [3] are shown in the same figures and reproduce the identity and relative ordering of the major intermediate species observed by experiment. $\mathrm{CH}_{3} \mathrm{OH}$ and $\mathrm{CH}_{2} \mathrm{O}$ are computed to be the major intermediates formed in all flames, as observed in experiment. The computed and experimental peak $\mathrm{CH}_{2} \mathrm{O}$ mole fractions both show only modest increase with increased equivalence ratio. However, the computed peak $\mathrm{CH}_{3} \mathrm{OH}$ mole fractions increase by close to a factor of two from $\Phi=1.0$ to $\Phi=1.8$, while experiment shows only $\sim 50 \%$ more $\mathrm{CH}_{3} \mathrm{OH}$ for the $\Phi=1.8$ flame relative to the $\Phi=1.0$ flame. The same relation has the peak $\mathrm{CH}_{4}$ measurement increase by $\sim 50 \%$. Model computation are always within $\sim 40 \%$ of experiment and reproduce this experimental behavior well. The spatial formation and consumption of $\mathrm{CH}_{3}$ radicals are also well reproduced by the kinetic model. However, somewhat characteristically for flame-sampling experiments, the computed $\mathrm{CH}_{3}$ mole fractions are consistently higher than observed by experiment. It is expected that a large portion of this disagreement may be accounted for by the loss of methyl radicals on the sampling cone upstream of the molecular beam.

Despite the absence of carbon-to-carbon bonds in the fuel molecular structure both experiment and kinetic model computations show ethylene formation. However the kinetic model fails to show the same level of transferability to the measured acetylene profiles which are computed to be $\sim 30 \%$ of the measured values. Computed acetaldehyde mole fractions are almost a factor of three lower than experiment. Insight into the fundamental chemical kinetic processes responsible for the formation of the detected intermediates and explanation of the minor discrepancies between model and experiment may be obtained by the detailed chemical flux and uncertainty analyses which follow.

A chemical flux analyses for the species presented in Figs. 2 and 3 has been performed within the reaction zone $(0-7 \mathrm{~mm}$ from the burner), where the mechanistically significant reactions occur. Tables 2-4 report those reactions most significantly contributing to the chemical flux for each measured species for the stoichiome- tric case as a representative flame computation. Flux analyses for the alkyl radicals formed by abstraction from MF are also included as these species are central to radical production in the flame.

The radical rich nature of these particular flames, a consequence of both the low-pressure and high fuel/oxidizer loads, enhances the role of hydrogen abstraction compared to some of the other reported experiments on MF that were conducted at higher pressures under more fuel dilute conditions [3]. As such, the experiments reported herein provide a stringent test of the employed rate constants for hydrogen abstraction from MF.

Indeed the chemical flux analyses, Tables 2-4, show that hydrogen abstraction is the largest process consuming fuel, accounting for $59 \%$ of all fuel consumed, with abstraction by ${ }^{\circ} \mathrm{H}(31 \%), \mathrm{OH}$ (17.4\%) and " $\mathrm{O}(7.0 \%)$ the largest contributors. Hydrogen abstraction from the methyl position (to form the methyl formyl, ${ }^{-} \mathrm{CH}_{2} \mathrm{OCHO}$, radical) is favored by slightly more than a factor of two over abstraction from the carbonyl position (to form the methoxy formyl, $\mathrm{CH}_{3} \mathrm{OC} \cdot \mathrm{O}$, radical). The remaining fuel fraction is consumed by the molecular elimination reactions of $\mathrm{MF} \leftrightarrows \mathrm{CH}_{3} \mathrm{OH}+\mathrm{CO}$ and $\mathrm{MF} \leftrightarrows \mathrm{CH}_{4}+\mathrm{CO}_{2}$ which account for $38 \%$ and $3 \%$ of fuel consumption respectively. Direct evidence of the activities of the primary MF decomposition channel is provided by the observed methanol concentrations reported in Fig. 3. Methanol formation is almost totally attributed to the concerted elimination of fuel; hydrogen abstraction from fuel by the methoxy radical $\left(\mathrm{CH}_{3} \mathrm{O}^{*}\right)$ makes a small contribution, but this radical is ostensibly formed by oxidation of the produced methanol fraction. The kinetic model shows that the reaction of $\mathrm{MF} \leftrightarrows \mathrm{CH}_{4}+\mathrm{CO}_{2}$ provides a significant contribution to total methane formation, $\sim 50 \%$, Table 3 . The rate constant computations of Metcalfe et al. [7] are evaluated against these experimental data later.

Figures 3 and 4 show that formaldehyde formation is well captured by the model over all conditions. The chemistry responsible for the formaldehyde profile is complex, as depicted by Table 2, but the decomposition of the methyl formyl radical ( ${ }^{\circ} \mathrm{CH}_{2} \mathrm{OCHO}$ ) radical is a prominent process. Figure 3 also shows that the model reproduces the peak $\mathrm{CH}_{3}$ concentrations always within a factor of two. Struckmeier et al. [19] report that under conditions comparable to those of this study, measured methyl radical concentrations may be in deviation by up to a factor of two from the true values. They recommend a modeling metric of reproducing the width and potential symmetry of the experimental value.

By this qualification, and considering the expected radical loses on the sampling cone surface, the computed $\mathrm{CH}_{3}$ profiles are in agreement with experiment. This deduction is important to the wider goals of the study. Table 3 shows that $60 \%$ of total methyl radical is produced by the decomposition of the $\mathrm{CH}_{3} \mathrm{OCO}$ radical. The decomposition of this species has been studied previously, e.g. $[20,21]$, and is therefore not a significant uncertainty in the kinetic model. Though not shown here, it is noted that if the rate constants 
Table 2

Contributions to the chemically reacting flux for the $\Phi=1.0$ flame in the region of $0-7 \mathrm{~mm}$ from the burner surface; reactants.

\begin{tabular}{|c|c|c|c|c|}
\hline \multirow[t]{2}{*}{ Species } & \multicolumn{2}{|c|}{ Contribution to production reaction flux } & \multicolumn{2}{|c|}{ Contribution to consumption reaction flux } \\
\hline & Reaction & $\%$ & Reaction & $\%$ \\
\hline $\mathrm{CH}_{3} \mathrm{OCHO}$ & & & $\begin{array}{l}\mathrm{CH}_{3} \mathrm{OCHO}+\mathrm{M} \leftrightarrows \mathrm{CH}_{3} \mathrm{OH}+\mathrm{CO}+\mathrm{M} \\
\mathrm{CH}_{3} \mathrm{OCHO}+\mathrm{H} \leftrightarrows \mathrm{CH}_{2} \mathrm{OCHO}+\mathrm{H}_{2} \\
\mathrm{CH}_{3} \mathrm{OCHO}+\mathrm{OH} \leftrightarrows \mathrm{CH}_{2} \mathrm{OCHO}+\mathrm{H}_{2} \mathrm{O} \\
\mathrm{CH}_{3} \mathrm{OCHO}+\mathrm{H} 8 \leftrightarrows \mathrm{CH}_{3} \mathrm{OCO}+\mathrm{H}_{2} \\
\mathrm{CH}_{3} \mathrm{OCHO}+\mathrm{OH} \leftrightarrows \mathrm{CH}_{3} \mathrm{OCO}+\mathrm{H}_{2} \mathrm{O} \\
\mathrm{CH}_{3} \mathrm{OCHO}+\mathrm{O} \leftrightarrows \mathrm{CH}_{2} \mathrm{OCHO}+\mathrm{OH} \\
\mathrm{CH}_{3} \mathrm{OCHO}+\mathrm{M} \leftrightarrows \mathrm{CH}_{4}+\mathrm{CO}_{2}+\mathrm{M} \\
\mathrm{CH}_{3} \mathrm{OCHO}+\mathrm{O} \leftrightarrows \mathrm{CH}_{3} \mathrm{OCO}+\mathrm{OH}\end{array}$ & $\begin{array}{l}38.4 \\
21.2 \\
12.3 \\
9.6 \\
5.4 \\
4.9 \\
3.2 \\
2.1\end{array}$ \\
\hline $\mathrm{CH}_{2} \mathrm{OCHO}$ & $\begin{array}{l}\mathrm{CH}_{3} \mathrm{OCHO}+\mathrm{H} \leftrightarrows \mathrm{CH}_{2} \mathrm{OCHO}+\mathrm{H}_{2} \\
\mathrm{CH}_{3} \mathrm{OCHO}+\mathrm{OH} \leftrightarrows \mathrm{CH}_{2} \mathrm{OCHO}+\mathrm{H}_{2} \mathrm{O} \\
\mathrm{CH}_{3} \mathrm{OCHO}+\mathrm{O} \leftrightarrows \mathrm{CH}_{2} \mathrm{OCHO}+\mathrm{OH}\end{array}$ & $\begin{array}{l}55.0 \\
31.9 \\
12.8\end{array}$ & $\begin{array}{l}\mathrm{CH}_{2} \mathrm{OCHO} \leftrightarrows \mathrm{CH}_{2} \mathrm{O}+\mathrm{HCO} \\
\mathrm{CH}_{2} \mathrm{OCHO} \leftrightarrows \mathrm{CH}_{3} \mathrm{OCO} \\
\mathrm{CH}_{2} \mathrm{OCHO} \leftrightarrows \mathrm{CH}_{2} \mathrm{OCHO}+\mathrm{H} \\
\mathrm{CH}_{3}+\mathrm{CH}_{2} \mathrm{OCHO} \leftrightarrows \mathrm{CH}_{3} \mathrm{CH}_{2} \mathrm{OCHO}\end{array}$ & $\begin{array}{l}85.2 \\
5.3 \\
3.5 \\
1.7\end{array}$ \\
\hline $\mathrm{CH}_{3} \mathrm{OCO}$ & $\begin{array}{l}\mathrm{CH}_{3} \mathrm{OCHO}+\mathrm{H} \leftrightarrows \mathrm{CH}_{3} \mathrm{OCO}+\mathrm{H}_{2} \\
\mathrm{CH}_{3} \mathrm{OCHO}+\mathrm{OH} \leftrightarrows \mathrm{CH}_{3} \mathrm{OCO}+\mathrm{H}_{2} \mathrm{O} \\
\mathrm{CH}_{3} \mathrm{OCHO}+\mathrm{O} \leftrightarrows \mathrm{CH}_{3} \mathrm{OCO}+\mathrm{OH} \\
\mathrm{CH}_{2} \mathrm{OCHO} \leftrightarrows \mathrm{CH}_{3} \mathrm{OCO}\end{array}$ & $\begin{array}{l}47.4 \\
26.8 \\
10.2 \\
10.1\end{array}$ & $\begin{array}{l}\mathrm{CH}_{3} \mathrm{OCO} \leftrightarrows \mathrm{CH}_{3}+\mathrm{CO}_{2} \\
\mathrm{CH}_{3} \mathrm{OCO} \leftrightarrows \mathrm{CH}_{3} \mathrm{O}+\mathrm{CO}\end{array}$ & $\begin{array}{l}80.6 \\
19.4\end{array}$ \\
\hline $\mathrm{O}_{2}$ & $\begin{array}{l}\mathrm{HO}_{2}+\mathrm{OH} \leftrightarrows \mathrm{H}_{2} \mathrm{O}+\mathrm{O}_{2} \\
\mathrm{HO}_{2}+\mathrm{H} \leftrightarrows \mathrm{H}_{2}+\mathrm{O}_{2} \\
\mathrm{HO}_{2}+\mathrm{HO}_{2} \leftrightarrows \mathrm{H}_{2} \mathrm{O}_{2}+\mathrm{O}_{2} \\
\mathrm{HO}_{2}+\mathrm{O} \leftrightarrows \mathrm{O}_{2}+\mathrm{OH}\end{array}$ & $\begin{array}{l}51.1 \\
20.2 \\
6.9 \\
15.5\end{array}$ & $\begin{array}{l}\mathrm{H}+\mathrm{O}_{2} \leftrightarrows \mathrm{O}+\mathrm{OH} \\
\mathrm{HCO}+\mathrm{O}_{2} \leftrightarrows \mathrm{CO}+\mathrm{HO}_{2} \\
\mathrm{CH}_{2} \mathrm{OH}+\mathrm{O}_{2} \leftrightarrows \mathrm{CH}_{2} \mathrm{O}+\mathrm{HO}_{2}\end{array}$ & $\begin{array}{l}58.8 \\
21.5 \\
14.5\end{array}$ \\
\hline
\end{tabular}

Table 3

Contributions to the chemically reacting flux for the $\Phi=1.0$ flame in the region of $0-7 \mathrm{~mm}$ from the burner surface; intermediates.

\begin{tabular}{|c|c|c|c|c|}
\hline \multirow[t]{2}{*}{ Species } & \multicolumn{2}{|l|}{ Contribution to production reaction flux } & \multicolumn{2}{|c|}{ Contribution to consumption reaction flux } \\
\hline & Reaction & $\%$ & Reaction & $\%$ \\
\hline $\mathrm{H}_{2}$ & $\begin{array}{l}\mathrm{CH}_{2} \mathrm{O}+\mathrm{H} \leftrightarrows \mathrm{HCO}+\mathrm{H}_{2} \\
\mathrm{CH}_{3} \mathrm{OCHO}+\mathrm{H} \leftrightarrows \mathrm{CH}_{2} \mathrm{OCHO}+\mathrm{H}_{2} \\
\mathrm{HCO}+\mathrm{H} \leftrightarrows \mathrm{CO}+\mathrm{H}_{2} \\
\mathrm{CH}_{3} \mathrm{OCHO}+\mathrm{H} \leftrightarrows \mathrm{CH}_{3} \mathrm{OCO}+\mathrm{H}_{2} \\
\mathrm{CH}_{3} \mathrm{OH}+\mathrm{H} \leftrightarrows \mathrm{CH}_{2} \mathrm{OH}+\mathrm{H}_{2} \\
\mathrm{HO}_{2}+\mathrm{H} \leftrightarrows \mathrm{H}_{2}+\mathrm{O}_{2}\end{array}$ & $\begin{array}{l}42.2 \\
17.8 \\
10.2 \\
8.1 \\
7.2 \\
5.3\end{array}$ & $\begin{array}{l}\mathrm{H}_{2}+\mathrm{OH} \leftrightarrows \mathrm{H}_{2} \mathrm{O}+\mathrm{H} \\
\mathrm{O}+\mathrm{H}_{2} \leftrightarrows \mathrm{H}+\mathrm{OH}\end{array}$ & $\begin{array}{l}60.8 \\
39.2\end{array}$ \\
\hline $\mathrm{CH}_{2} \mathrm{O}$ & $\begin{array}{l}\mathrm{CH}_{2} \mathrm{OCHO} \leftrightarrows \mathrm{CH}_{2} \mathrm{O}+\mathrm{HCO} \\
\mathrm{CH}_{2} \mathrm{OH}+\mathrm{O}_{2} \leftrightarrows \mathrm{CH}_{2} \mathrm{O}+\mathrm{HO}_{2} \\
\mathrm{CH}_{3}+\mathrm{O} \leftrightarrows \mathrm{CH}_{2} \mathrm{O}+\mathrm{H} \\
\mathrm{CH}_{3} \mathrm{O}+\mathrm{M} \leftrightarrows \mathrm{CH}_{2} \mathrm{O}+\mathrm{H}+\mathrm{M}\end{array}$ & $\begin{array}{l}35.5 \\
29.2 \\
11.3 \\
8.5\end{array}$ & $\begin{array}{l}\mathrm{CH}_{2} \mathrm{O}+\mathrm{OH} \leftrightarrows \mathrm{CH} 2 \mathrm{O} 2 \mathrm{H} \\
\mathrm{CH}_{2} \mathrm{O}+\mathrm{H} \leftrightarrows \mathrm{HCO}+\mathrm{H}_{2} \\
\mathrm{CH}_{2} \mathrm{O}+\mathrm{OH} \leftrightarrows \mathrm{HCO}+\mathrm{H}_{2} \mathrm{O}\end{array}$ & $\begin{array}{l}73.7 \\
18.2 \\
10.5\end{array}$ \\
\hline $\mathrm{CH}_{3} \mathrm{OH}$ & $\begin{array}{l}\mathrm{CH}_{3} \mathrm{OCHO}+\mathrm{M} \leftrightarrows \mathrm{CH}_{3} \mathrm{OH}+\mathrm{CO}+\mathrm{M} \\
\mathrm{CH}_{3} \mathrm{OCHO}+\mathrm{CH}_{3} \mathrm{O} \leftrightarrows \mathrm{CH}_{3} \mathrm{OCO}+\mathrm{CH}_{3} \mathrm{OH}\end{array}$ & $\begin{array}{l}96.4 \\
1.5\end{array}$ & $\begin{array}{l}\mathrm{CH}_{3} \mathrm{OH}+\mathrm{OH} \leftrightarrows \mathrm{CH}_{2} \mathrm{OH}+\mathrm{H}_{2} \mathrm{O} \\
\mathrm{CH}_{3} \mathrm{OH}+\mathrm{O} \leftrightarrows \mathrm{CH}_{2} \mathrm{OH}+\mathrm{OH} \\
\mathrm{CH}_{3} \mathrm{OH}+\mathrm{H} \leftrightarrows \mathrm{CH}_{2} \mathrm{OH}+\mathrm{H}_{2} \\
\mathrm{CH}_{3} \mathrm{OH}+\mathrm{OH} \leftrightarrows \mathrm{CH}_{3} \mathrm{O}+\mathrm{H}_{2} \mathrm{O} \\
\mathrm{CH}_{3} \mathrm{OH}+\mathrm{H} \leftrightarrows \mathrm{CH}_{3} \mathrm{O}+\mathrm{H}_{2}\end{array}$ & $\begin{array}{l}28.5 \\
28.5 \\
21.6 \\
21.3 \\
4.6\end{array}$ \\
\hline $\mathrm{CH}_{4}$ & $\begin{array}{l}\mathrm{CH}_{3} \mathrm{OCHO}+\mathrm{M} \leftrightarrows \mathrm{CH}_{4}+\mathrm{CO}_{2}+\mathrm{M} \\
\mathrm{HCO}+\mathrm{CH}_{3} \leftrightarrows \mathrm{CO}+\mathrm{CH}_{4} \\
\mathrm{CH}_{3}+\mathrm{HO}_{2} \leftrightarrows \mathrm{CH}_{4}+\mathrm{O}_{2} \\
\mathrm{CH}_{2} \mathrm{O}+\mathrm{CH}_{3} \leftrightarrows \mathrm{HCO}+\mathrm{CH}_{4} \\
\mathrm{CH}_{3} \mathrm{O}+\mathrm{CH}_{3} \leftrightarrows \mathrm{CH}_{2} \mathrm{O}+\mathrm{CH}_{4}\end{array}$ & $\begin{array}{l}49.3 \\
22.2 \\
13.5 \\
4.8 \\
4.3\end{array}$ & $\begin{array}{l}\mathrm{CH}_{4}+\mathrm{OH} \leftrightarrows \mathrm{CH}_{3}+\mathrm{H}_{2} \mathrm{O} \\
\mathrm{CH}_{4}+\mathrm{H} \leftrightarrows \mathrm{CH}_{3}+\mathrm{H}_{2} \\
\mathrm{CH}_{4}+\mathrm{O} \leftrightarrows \mathrm{CH}_{3}+\mathrm{OH}\end{array}$ & $\begin{array}{l}45.3 \\
34.7 \\
19.8\end{array}$ \\
\hline $\mathrm{CH}_{3}$ & $\begin{array}{l}\mathrm{CH}_{3} \mathrm{OCO} \leftrightarrows \mathrm{CH}_{3}+\mathrm{CO}_{2} \\
\mathrm{CH}_{4}+\mathrm{OH} \leftrightarrows \mathrm{CH}_{3}+\mathrm{H}_{2} \mathrm{O} \\
\mathrm{CH}_{4}+\mathrm{H} \leftrightarrows \mathrm{CH}_{3}+\mathrm{H}_{2} \\
\mathrm{CH}_{3} \mathrm{O}+\mathrm{H} \leftrightarrows \mathrm{CH}_{3}+\mathrm{OH} \\
\mathrm{CH}_{4}+\mathrm{O} \leftrightarrows \mathrm{CH}_{3}+\mathrm{OH}\end{array}$ & $\begin{array}{l}59.6 \\
10.7 \\
8.3 \\
5.5 \\
4.7\end{array}$ & $\begin{array}{l}\mathrm{CH}_{3}+\mathrm{O} \leftrightarrows \mathrm{CH}_{2} \mathrm{O}+\mathrm{H} \\
\mathrm{CH}_{3}+\mathrm{OH} \leftrightarrows \mathrm{CH}_{2(\mathrm{~S})}+\mathrm{H}_{2} \mathrm{O} \\
\mathrm{CH}_{3}+\mathrm{HO}_{2} \leftrightarrows \mathrm{CH}_{3} \mathrm{O}+\mathrm{OH} \\
\mathrm{HCO}+\mathrm{CH}_{3} \leftrightarrows \mathrm{CO}+\mathrm{CH}_{4}\end{array}$ & $\begin{array}{l}38.5 \\
21.9 \\
14.5 \\
5.3\end{array}$ \\
\hline $\mathrm{C}_{2} \mathrm{H}_{4}$ & $\begin{array}{l}\mathrm{CH}_{3} \mathrm{CH}_{2} \mathrm{OCHO} \leftrightarrows \mathrm{HCOOH}+\mathrm{C}_{2} \mathrm{H}_{4} \\
\mathrm{CH}_{2} \mathrm{CH}_{2} \mathrm{OCHO} \leftrightarrows \mathrm{C}_{2} \mathrm{H}_{4}+\mathrm{OCHO} \\
\mathrm{C}_{2} \mathrm{H}_{5}(+\mathrm{M}) \leftrightarrows \mathrm{H}+\mathrm{C}_{2} \mathrm{H}_{4}(+\mathrm{M}) \\
\mathrm{CH}_{3}+\mathrm{CH}_{2} \leftrightarrows \mathrm{C}_{2} \mathrm{H}_{4}+\mathrm{H}\end{array}$ & $\begin{array}{l}66.7 \\
11.7 \\
9.5 \\
8.4\end{array}$ & $\begin{array}{l}\mathrm{C}_{2} \mathrm{H}_{4}+\mathrm{O} \leftrightarrows \mathrm{CH}_{3}+\mathrm{HCO} \\
\mathrm{C}_{2} \mathrm{H}_{4}+\mathrm{OH} \leftrightarrows \mathrm{C}_{2} \mathrm{H}_{3}+\mathrm{H}_{2} \mathrm{O} \\
\mathrm{C}_{2} \mathrm{H}_{4}+\mathrm{H} \leftrightarrows \mathrm{C}_{2} \mathrm{H}_{3}+\mathrm{H}_{2} \\
\mathrm{C}_{2} \mathrm{H}_{4}+\mathrm{O} \leftrightarrows \mathrm{CH}_{2} \mathrm{CHO}+\mathrm{H}\end{array}$ & $\begin{array}{l}33.4 \\
25.1 \\
20.6 \\
19.4\end{array}$ \\
\hline $\mathrm{C}_{2} \mathrm{H}_{2}$ & $\begin{array}{l}\mathrm{C}_{2} \mathrm{H}_{3}(+\mathrm{M}) \leftrightarrows \mathrm{C}_{2} \mathrm{H}_{2}+\mathrm{H}(+\mathrm{M}) \\
\mathrm{C}_{2} \mathrm{H}_{3}+\mathrm{H} \leftrightarrows \mathrm{C}_{2} \mathrm{H}_{2}+\mathrm{H}_{2} \\
\mathrm{C}_{2} \mathrm{H}_{3}+\mathrm{OH} \leftrightarrows \mathrm{C}_{2} \mathrm{H}_{2}+\mathrm{H}_{2} \mathrm{O}\end{array}$ & $\begin{array}{l}65.4 \\
23.4 \\
4.4\end{array}$ & $\begin{array}{l}\mathrm{C}_{2} \mathrm{H}_{2}+\mathrm{O} \leftrightarrows \mathrm{HCCO}+\mathrm{H} \\
\mathrm{C}_{2} \mathrm{H}_{2}+\mathrm{O} \leftrightarrows \mathrm{CH}_{2}+\mathrm{CO} \\
\mathrm{C}_{2} \mathrm{H}_{2}+\mathrm{OH} \leftrightarrows \mathrm{CH}_{2} \mathrm{CO}+\mathrm{H}\end{array}$ & $\begin{array}{l}61.2 \\
31.5 \\
7.2\end{array}$ \\
\hline $\mathrm{CH}_{3} \mathrm{CHO}$ & $\begin{array}{l}\mathrm{CH}_{3}+\mathrm{HCO} \leftrightarrows \mathrm{CH}_{3} \mathrm{CHO} \\
\mathrm{C}_{2} \mathrm{H}_{5}+\mathrm{O} \leftrightarrows \mathrm{CH}_{3} \mathrm{CHO}+\mathrm{H}\end{array}$ & $\begin{array}{l}61.6 \\
20.2\end{array}$ & $\begin{array}{l}\mathrm{CH}_{3} \mathrm{CHO}+\mathrm{OH} \leftrightarrows \mathrm{CH}_{2} \mathrm{CHO}+\mathrm{H}_{2} \mathrm{O} \\
\mathrm{CH}_{3} \mathrm{CHO}+\mathrm{H} \leftrightarrows \mathrm{CH}_{3} \mathrm{CO}+\mathrm{H}_{2} \\
\mathrm{CH}_{3} \mathrm{CHO}+\mathrm{OH} \leftrightarrows \mathrm{CH}_{3}+\mathrm{HCOOH} \\
\mathrm{CH}_{3} \mathrm{CHO}+\mathrm{O} \leftrightarrows \mathrm{CH}_{3} \mathrm{CO}+\mathrm{OH}\end{array}$ & $\begin{array}{l}40.3 \\
36.3 \\
10.5 \\
10.5\end{array}$ \\
\hline
\end{tabular}


Table 4

Contributions to the chemically reacting flux for the $\Phi=1.0$ flame in the region of $0-7 \mathrm{~mm}$ from the burner surface; products.

\begin{tabular}{|c|c|c|c|c|}
\hline \multirow[t]{2}{*}{ Species } & \multicolumn{2}{|c|}{ Contribution to production reaction flux } & \multicolumn{2}{|c|}{ Contribution to consumption reaction flux } \\
\hline & Reaction & $\%$ & Reaction & $\%$ \\
\hline $\mathrm{CO}_{2}$ & $\begin{array}{l}\mathrm{CO}+\mathrm{OH} \leftrightarrows \mathrm{CO}_{2}+\mathrm{H} \\
\mathrm{CH}_{3} \mathrm{OCO} \leftrightarrows \mathrm{CH}_{3}+\mathrm{CO}_{2} \\
\mathrm{CH}_{3} \mathrm{OCHO}+\mathrm{M} \leftrightarrows \mathrm{CH}_{4}+\mathrm{CO}_{2}+\mathrm{M} \\
\mathrm{HCOOH}+\mathrm{H} \leftrightarrows \mathrm{H}_{2}+\mathrm{CO}_{2}+\mathrm{H}\end{array}$ & $\begin{array}{l}73.4 \\
12.9 \\
2.6 \\
2.4\end{array}$ & & \\
\hline $\mathrm{CO}$ & $\begin{array}{l}\mathrm{HCO}+\mathrm{M} \leftrightarrows \mathrm{H}+\mathrm{CO}+\mathrm{M} \\
\mathrm{HCO}+\mathrm{O}_{2} \leftrightarrows \mathrm{CO}+\mathrm{HO}_{2} \\
\mathrm{CH}_{3} \mathrm{OCHO}+\mathrm{M} \leftrightarrows \mathrm{CH}_{3} \mathrm{OH}+\mathrm{CO}+\mathrm{M} \\
\mathrm{HCO}+\mathrm{H} \leftrightarrows \mathrm{CO}+\mathrm{H}_{2}\end{array}$ & $\begin{array}{l}32.6 \\
24.3 \\
23.3 \\
7.4\end{array}$ & $\begin{array}{l}\mathrm{CO}+\mathrm{OH} \leftrightarrows \mathrm{CO}_{2}+\mathrm{H} \\
\mathrm{CH}_{3} \mathrm{O}+\mathrm{CO} \leftrightarrows \mathrm{CH}_{3}+\mathrm{CO}_{2} \\
\mathrm{CO}+\mathrm{HO}_{2} \leftrightarrows \mathrm{CO}_{2}+\mathrm{OH}\end{array}$ & $\begin{array}{l}98.6 \\
0.7 \\
0.5\end{array}$ \\
\hline $\mathrm{H}_{2} \mathrm{O}$ & $\begin{array}{l}\mathrm{H}_{2}+\mathrm{OH} \leftrightarrows \mathrm{H}_{2} \mathrm{O}+\mathrm{H} \\
\mathrm{CH}_{2} \mathrm{O}+\mathrm{OH} \leftrightarrows \mathrm{HCO}+\mathrm{H}_{2} \mathrm{O} \\
\mathrm{HO}_{2}+\mathrm{OH} \leftrightarrows \mathrm{O}_{2}+\mathrm{H}_{2} \mathrm{O} \\
\mathrm{CH}_{3} \mathrm{OCHO}+\mathrm{OH} \leftrightarrows \mathrm{CH}_{2} \mathrm{OCHO}+\mathrm{H}_{2} \mathrm{O}\end{array}$ & $\begin{array}{l}34.5 \\
21.0 \\
9.0 \\
7.0\end{array}$ & & \\
\hline
\end{tabular}

for ' $\mathrm{CH}_{3}+\mathrm{CO}_{2} / \mathrm{CH}_{3} \mathrm{O} \cdot+\mathrm{CO} \leftrightarrows \mathrm{CH}_{3} \mathrm{OC} \cdot \mathrm{O}$ as calculated by Huynh et al. [20] are adopted, the peak $\mathrm{CH}_{3}$ mole fraction is reduced. However so too is the peak $\mathrm{CH}_{4}$ mole fraction, thus the rate constants for these reactions of Glaude et al. [21] have been retained. Glaude et al. employed a coupled CBS-Q//B3LYP/6-31G(d,p) method to calculate rate constants for ${ }^{-} \mathrm{CH}_{3}+\mathrm{CO}_{2} / \mathrm{CH}_{3} \mathrm{O}+\mathrm{CO} \leftrightarrows \mathrm{CH}_{3} \mathrm{OC} \cdot \mathrm{O}$, with the critical branching ratio computed from thermochemistry. Huynh et al. [20] used a G3B3 composite method and calculated both forward and reverse rate constants for each channel. Their rate constant for ${ }^{-} \mathrm{CH}_{3}+\mathrm{CO}_{2} \leftrightarrows \mathrm{CH}_{3} \mathrm{OC} \cdot \mathrm{O}$ is more than an order of magnitude slower than the expression of Glaude et al. Although both tested expressions for $\mathrm{CH}_{3} \mathrm{O}^{\cdot}+\mathrm{CO} \leftrightarrows \mathrm{CH}_{3} \mathrm{OC} \cdot \mathrm{O}$ are in much better agreement, the rate constant of Huynh et al. is approximately a factor of two slower than that of Glaude et al. The accurate computation of this distinct beta-scission product, $\mathrm{CH}_{3}$ radical, is a direct indication that the rate constants for hydrogen abstraction from the carbonyl position have been accurately prescribed. Although the chemical flux analysis shows that formaldehyde production is not to the same degree, the result of an isolated beta-scission process, we may be similarly confident as to the appropriateness of the description of the formation and consumption of the $\cdot \mathrm{CH}_{2} \mathrm{OCHO}$ radical.

\subsection{Uncertainty analysis}

Uncertainties in the experimental measurements have been discussed. In order to make a more complete assessment of the performance of the kinetic model in describing MF oxidation, it is necessary to evaluate the impact of modeling uncertainties. Chemical kinetic inputs and the assumptions necessary to simplify the experimental environment to the point where it can be simulated with detailed chemical kinetics must be considered.

\subsubsection{Flame simulation}

Due to innate heat losses, the temperature profile of a burnerstabilized flame is a required and overriding controlling input to the simulation of this reacting flow that must be determined by measurement. Consequently it is prudent to assess the impact of reasonable errors in this measured parameter on kinetic modeling computations. As part of their recent investigation, Struckmeier et al. [19] have reviewed the extent of potential modifications to the unperturbed temperature field caused by the insertion of the MBMS flame-sampling cone into low-pressure flames. Temperature measurements of sampling-cone-perturbed flames are shown to differ by up to $400 \mathrm{~K}$. This is important as unperturbed flames are commonly assumed in simulation. The measurements performed within the reaction zone are of greatest importance to kinetic model development, as it is here where mechanistic information of the oxidation process is available.
Therefore the sensitivity of our kinetic model computations are tested by performing four additional computations with assumed temperature profiles for the representative stoichiometric flame. The inlet and peak flame temperatures are fixed at the measured values, of $500 \mathrm{~K}$ and $2122 \mathrm{~K}$ at $0 \mathrm{~mm}$ and $6 \mathrm{~mm}$ respectively from the burner surface. The temperature field between these points is perturbed relative to the measured temperatures by $\pm 200 \mathrm{~K}$, producing a $400 \mathrm{~K}$ differential, and by $\pm 100 \mathrm{~K}$ producing a $200 \mathrm{~K}$ differential respectively. Model computations with the perturbed temperature profiles are presented by the shaded areas in Fig. 5.

In a strong indication that the measured temperature profile is accurate, the species measured from the stoichiometric flame are generally well computed if this temperature profile is used. Only major species measurements $0-3 \mathrm{~mm}$ from the burner surface are somewhat poorly reproduced as shown in Figs. 2 and 3. It is shown by Fig. 5a that if the assumed temperature profiles due to conceivable sampling cone perturbations are employed, only the $\mathrm{CO}$ and $\mathrm{CO}_{2}$ measurements within $\sim 1 \mathrm{~mm}$ of the burner lie outside the bounds of model computations. Moreover, model computations are subject to a pronounced translation of $\sim 1.5-2 \mathrm{~mm}$ along the $x$-coordinate. This is a partial explanation for the adjustments required to model computations performed with the measured temperature field to be consistent with experimentally determined argon profiles.

Figure $5 b$ and $c$ shows the effects of the assumed perturbations on the major intermediate species to be relatively minor and do not alter the mechanistic conclusions provided by the baseline computations. Crucially, the computed peak $\mathrm{CH}_{3} \mathrm{OH}, \mathrm{CH}_{2} \mathrm{O}$, and $\mathrm{CH}_{4}$ mole fractions that are mechanistically most significant to MF oxidation, are modified by less than a factor of two in the worst case and therefore still remain within the wider uncertainties of the measurement. For the $\pm 200 \mathrm{~K}$ representative case, all measurements fall within the bounds of computations accounting for the assumed perturbations to the temperature field, the only exception being measurements within $\sim 1-2 \mathrm{~mm}$ of the burner surface.

The effects of a more realistic uncertainty of $\pm 100 \mathrm{~K}$ in temperature measurements is provided by Fig. $5 \mathrm{c}$ which shows similar but more minor disturbances to those of Fig. 5b, $x$-coordinate translations of $<1 \mathrm{~mm}$ and only modest adjustments to computed peak species concentrations.

\subsubsection{Kinetic model, $M F$ decomposition}

Our recent kinetic modeling study has highlighted the molecular decomposition of methyl formate to principally form methanol and carbon monoxide, with an atypically low energy barrier [3] in contradiction of previous ab initio computations [6]. The low-pressure flame methanol measurements provide a further opportunity to evaluate rate constant descriptions for this process, especially in 

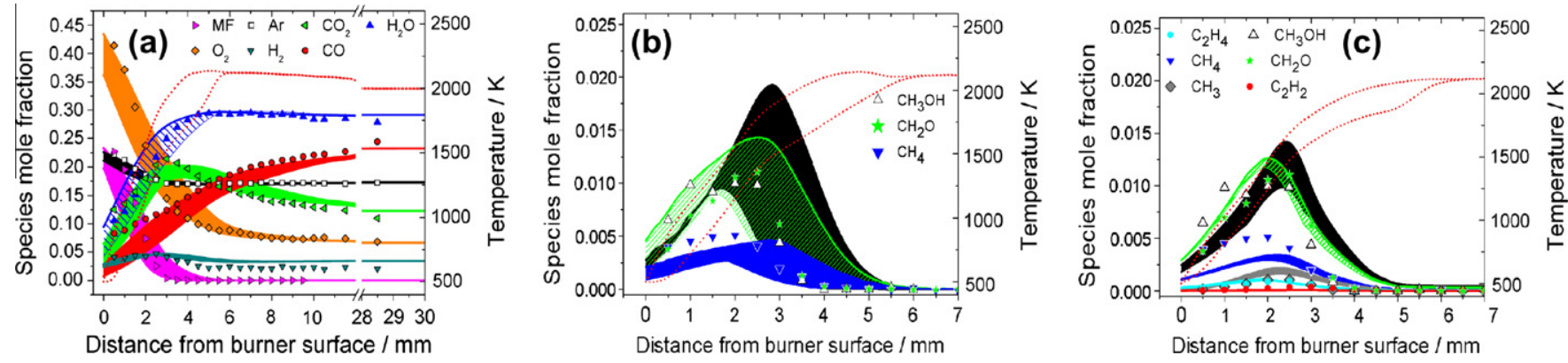

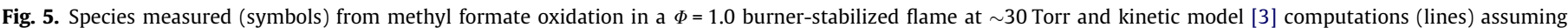

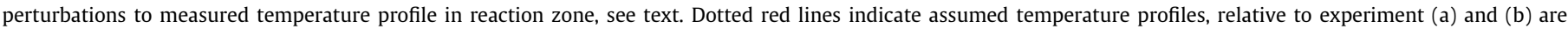
$\pm 200 \mathrm{~K}$, (c) $\pm 100 \mathrm{~K}$. Filled areas represent affect of temperature uncertainties on modeling computations.

light of the recent computational efforts of Metcalfe et al. [7]. Metcalfe et al. computed pressure-dependent rate constants for the three possible molecular decomposition reactions of this small methyl ester system with " $a b$ initio" methods. This work agrees with our prior conclusion of the apparent error in the computations of Francisco [6], but the calculated rate constants for the formation of methanol and carbon monoxide are lower than required to reproduce existing experimental data, from flow reactor studies in particular.

Given the lack of consensus on what is a principle kinetic modeling input for this system, we have evaluated our previous MF decomposition rate constant description and that of Metcalfe et al. [7] against the methanol measurements presented in this study. To do so, there are two basic uncertainties; (1) the value of the high-pressure limit rate constant and (2) the pressure-dependence of the rate constant. Obviously, at the low-pressures of these flames it is highly unlikely that MF decomposition reactions are at their high-pressure limit value but we will start by assuming that this is the case. If the high-pressure limit rate constants for $\mathrm{MF} \leftrightarrows \mathrm{CH}_{3} \mathrm{OH}+\mathrm{CO}$ from Dooley et al. [3] and Metcalfe et al. [7] are input to the kinetic model, computed methanol profiles are respectively factors of five and three larger than experiment.

Obviously a pressure dependent description is required for this reaction rate constant. Our MF kinetic model estimates the pressure-dependence of MF decomposition by quantum Rice-Ramsperger-Kassel (QRRK) theory as described by Chang et al. [22] and Sheng et al. [23]. A temperature independent value of $830 \mathrm{cal} \mathrm{mol}^{-1}$ for the collisional energy transfer parameter, $\Delta E_{(\text {down })}$ for argon bath gas and a high-pressure limit rate constant derived from MF pyrolysis measurements [3] are employed. $\Delta E_{(\text {down })}$ is an empirical parameter for which little reliable data is available, as such it is an obvious po- tential source of error in the estimation of the kinetics of pressure dependent systems. To quantify the effect of this and other variables on the computations of the kinetic model, a number of modifications were made to the description of MF decomposition. These are tested against the stoichiometric flame and their affects summarized in Table 5.

For our recommended high-pressure limit rate constant, the use of an alternative $\Delta E_{\text {(down) }}$ of $383 \mathrm{cal} \mathrm{mol}^{-1}$ reported by Hippler et al. [24] in a study of toluene decomposition, produces $58 \%$ of the peak $\mathrm{CH}_{3} \mathrm{OH}$ concentration for the baseline case. A common approximation in treating pressure dependent reactions is to assume that only one distinct body acts as collider, normally nitrogen for combustion environments. A curious observation from Fig. 2 is that the bath gas in the center of the reaction zone, where the intermediate species peak, is far from normal. For example for the stoichiometric flame at $2.5 \mathrm{~mm}$ from the burner surface the effective bath gas composition is a $\mathrm{MF} / \mathrm{H}_{2} / \mathrm{CO}_{2} / \mathrm{Ar} / \mathrm{CO}_{2} / \mathrm{H}_{2} \mathrm{O}$ mixture of $3.3 / 5.8 / 14.8 / 22.6 / 26 /$ 27.5 mole\%. Previously we had assumed MF decomposition reactions to have third body efficiencies based on similar reactions from GRI Mech 3.0 [25]. Computations assuming no collisional enhancement in rate constant produce a very similar $\mathrm{CH}_{3} \mathrm{OH}$ profile, only $5 \%$ lower in peak than the baseline simulation. An alternative method for estimating collisional efficiencies is to simply normalize the QRRK estimated rate constants at 30 Torr computed with the $\Delta E_{\text {(down) }}$ and Lennard-Jones parameters reported by Hippler et al. [24] for $\mathrm{H}_{2}, \mathrm{CO}_{2}, \mathrm{Ar}, \mathrm{CO}_{2}$ and $\mathrm{H}_{2} \mathrm{O}$. Model computations with this approach to MF decomposition result in a similar difference of just 3.5\% from the baseline value, Table 5 .

We may therefore conclude that one need not consider multiple third body properties to describe fuel decomposition in low-pressure flame environments. However, this is most likely not the case

Table 5

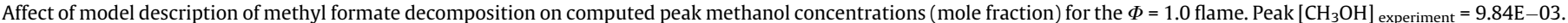

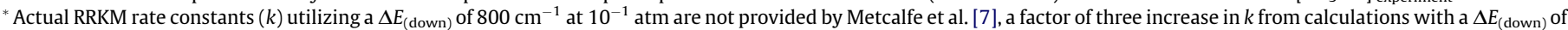
$400 \mathrm{~cm}^{-1}$ at $10^{-1} \mathrm{~atm}$ is estimated from their presented data.

\begin{tabular}{|c|c|c|c|}
\hline Model adjustment & $\begin{array}{l}\text { QRRK parameters } \operatorname{Ar} \Delta E_{\text {(down) }} / \\
\text { cal mol }^{-1}\end{array}$ & Comments & $\begin{array}{l}\text { Peak } \\
{\left[\mathrm{CH}_{3} \mathrm{OH}\right]}\end{array}$ \\
\hline Dooley et al. [3] (unadjusted) & $830[24,25]$ & Bath gas efficiencies assumed similar to $\mathrm{CH}_{3} \mathrm{OH}(+\mathrm{M})$ GRI Mech [27] & $1.14 \mathrm{E}-02$ \\
\hline $\begin{array}{l}\text { Fall-off treatment of MF } \\
\text { decomposition }\end{array}$ & $830[24,25]$ & Bath gas efficiencies not considered & $1.08 \mathrm{E}-02$ \\
\hline $\begin{array}{l}\text { Fall-off treatment of MF } \\
\text { decomposition }\end{array}$ & $383[26]$ & $\Delta E_{(\text {down) }}$ from Hippler et al. [26] efficiencies not considered & $6.61 \mathrm{E}-03$ \\
\hline $\begin{array}{l}\text { Fall-off treatment of MF } \\
\text { decomposition }\end{array}$ & $\begin{array}{l}\text { Specific for each bath gas } \\
\text { considered }\end{array}$ & $\begin{array}{l}\text { Efficiencies considered at ratio of QRRK computed rate constants at } 30 \text { Torr, } \\
\Delta E_{\text {(down) }} \text { and } \\
\text { Lennard-Jones parameters from Hippler et al. [26] for } \mathrm{M}=\mathrm{O}_{2}, \mathrm{MF}, \mathrm{CO}, \mathrm{CO}_{2} \text {, } \\
\mathrm{H}_{2} \mathrm{O}, \mathrm{H}_{2}\end{array}$ & $6.85 \mathrm{E}-03$ \\
\hline MF decomposition & $400 \mathrm{~cm}^{-1}\left(\sim 1150 \mathrm{cal} \mathrm{mol}^{-1}\right)$ & Rate constants at $10^{-2}$ atm from Metcalfe et al. [7] & $1.04 \mathrm{E}-03$ \\
\hline MF decomposition & $400 \mathrm{~cm}^{-1}\left(\sim 1150 \mathrm{cal} \mathrm{mol}^{-1}\right)$ & Rate constants at $10^{-1}$ atm from Metcalfe et al. [7] & $2.01 \mathrm{E}-03$ \\
\hline MF decomposition & $800 \mathrm{~cm}^{-1}\left(\sim 2300 \mathrm{cal} \mathrm{mol}^{-1}\right)^{*}$ & Rate constants at $10^{-1} \mathrm{~atm}$ from Metcalfe et al. [7] & $4.82 \mathrm{E}-03$ \\
\hline
\end{tabular}


for the more important elementary processes of the small species chemistry. This aspect of the kinetic modeling of low-pressure flames is outside the scope of the current study but certainly worthy of a dedicated investigation. Moreover, rate constants estimated by reasonable adjustments to the uncertain collisional energy transfer parameter, $\Delta E_{(\text {down) }}$ do not result in significantly different modeling results, peak methanol profiles are always within $40 \%$. Thus mechanistic arguments presented above are not affected by uncertainties in collisional energy transfer.

Finally, the Rice-Ramsperger-Kassel-Marcus (RRKM) theory computed rate constants of Metcalfe et al. are similarly tested. Kinetic model computations with the rate constants for MF decomposition quoted by Metcalfe et al. [7] at 7.6 Torr, result in only $~ 10 \%$ of the measured peak methanol mole fraction. If suggested rate constants estimated by a much larger $\Delta E_{\text {(down) }}$ of $2300 \mathrm{cal} \mathrm{mol}^{-1}$ $\left(800 \mathrm{~cm}^{-1}\right)$ and at a higher pressure of 76 Torr are employed, computed methanol concentrations are $\sim 50 \%$ of the measured peak. The MF decomposition parameters of Metcalfe and co-workers, even assuming reasonable uncertainty, compute methanol profiles that are consistently lower than experiment. However, given the discussed uncertainties in the estimation of pressure dependent chemical kinetics and in the experimental measurements, it is not possible to conclusively state that one description of MF decomposition is preferred over the other. Considering these measurements and previous higher pressure measurements [3] of MF decomposition/oxidation, where the complications of fall-off are of much reduced importance, further study is required to conclusively assign the kinetics of MF decomposition.

\subsubsection{Kinetic model, $C_{2}$ formation}

As the molecular structure of MF does not contain any carbon-tocarbon bonds, one would expect the formation of any $C_{2}$ species from oxidation to be minimal. Indeed in a similar study to that reported here, Westbrook et al. [1] have shown that the measured ethylene concentrations from esters which are composed of carbon-tocarbon bonds is as much as thirty times larger than for those esters which are not. The decomposition of the $\mathrm{CH}_{2} \mathrm{OCH}(\mathrm{O})$ species is slower than its counterpart alkyl radical and the model shows its consumption to be more complex, even allowing bimolecular addition and recombination reactions to be competitive with betascission, Table 2 . The model considers the recombination reactions of ${ }^{\circ} \mathrm{CH}_{3}+\mathrm{CH}_{2} \mathrm{OCHO} \leftrightarrows \mathrm{CH}_{3} \mathrm{CH}_{2} \mathrm{OCHO}$ and ${ }^{\circ} \mathrm{CH}_{3}+\mathrm{CH}_{3} \mathrm{O} \cdot \mathrm{C}(\mathrm{O}) \leftrightarrows$ $\mathrm{CH}_{3} \mathrm{OC}(\mathrm{O}) \mathrm{CH}_{3}$. Consideration of these processes allow for carboncarbon bond synthesis by the formation of the larger ethyl formate ester. Ethyl formate subsequently decomposes via the well known ethyl ester unimolecular elimination to form an acid and ethylene, to make the most significant contribution ( $70 \%$ of total) to the formation of $C_{2}$ species, Table 3. Figure 6 shows model computations of the $\mathrm{C}_{2}$ species with and without consideration of the larger ester

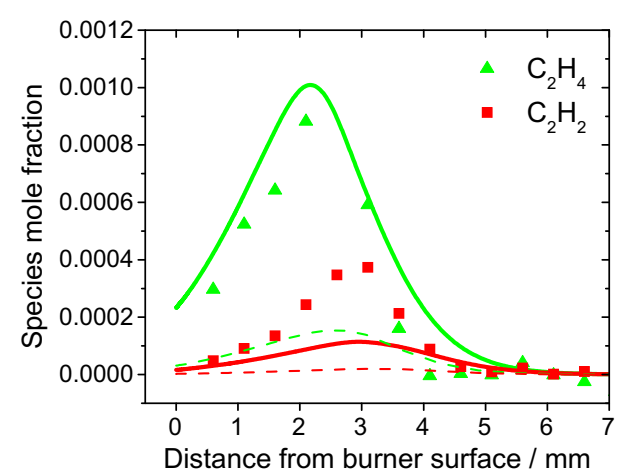

Fig. 6. $C_{2}$ formation in the phi $=1.0$ flame and model computations; considering ethyl formate/methyl acetate production/consumption (solid lines) and assuming no formation ethyl formate/methyl acetate (dotted lines).

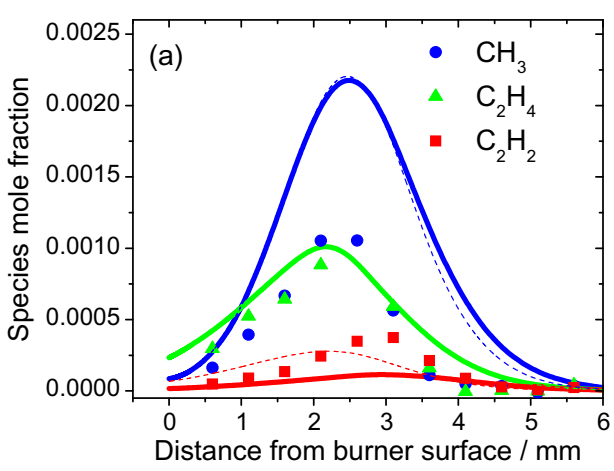

Fig. 7. Minor species (symbols) from methyl formate oxidation in a $\Phi=1.0,22$ Torr burner-stabilized flame and model computations: Dooley et al. [3] (solid lines) and Dooley et al. [3] with modified vinyl radical chemistry, (dashed lines), see text.

pathways. Ethyl formate and methyl acetate (both of $\mathrm{m} / \mathrm{z} 74$ ) were identified at low concentrations in the photoionization spectrum, lending credence to the occurrence of such radical-radical interactions.

Even with this consideration, there clearly remains a discrepancy between computed and measured $\mathrm{C}_{2}$ species, particularly at higher equivalence ratios. Reasonable perturbation to $\mathrm{CH}_{3}+\mathrm{CH}_{3}+(\mathrm{M})$ and other recombination reactions cannot improve computed $\mathrm{C}_{2} \mathrm{H}_{2}$ profiles significantly. It is apparent that increased model computation of $\mathrm{C}_{2} \mathrm{H}_{4}$ concentrations do not translate to comparable increases in $\mathrm{C}_{2} \mathrm{H}_{2}$ concentrations, for example see Fig. 6 .

In our previously developed model the $\mathrm{C}_{2} \mathrm{H}_{3}+\mathrm{O}_{2}$ branching ratio is adopted from Healy et al. [16]. Reasonable modification to this chemistry can affect the computed $\mathrm{C}_{2} \mathrm{H}_{2}$ profiles. Two treatments have been tested. Adopting the description in Curran et al. [26] results in a slightly improved comparison to experiment in the lower equivalence ratio flames, shown for the stoichiometric flame in Fig. 7. However, this performance degenerates in fuel-rich flames due to the decreased importance of $\mathrm{C}_{2} \mathrm{H}_{3}+\mathrm{O}_{2}$. Not shown in Fig. 7 , if the more recent description of Hansen et al. [27] is adopted, the computed $\mathrm{C}_{2} \mathrm{H}_{2}$ profiles are not improved relative to the original model because $\mathrm{C}_{2} \mathrm{H}_{2}+\mathrm{HO}_{2}$ is not considered as a direct product set. These tested modifications and comparisons are detailed as Supplementary material. Presently the reason for the discrepancy against $C_{2}$ species is unresolved but may indicate a route to acetylene formation which is not accounted for in the expected $\mathrm{C}_{2} \mathrm{H}_{6} \Rightarrow$ $\mathrm{C}_{2} \mathrm{H}_{4} \Rightarrow \mathrm{C}_{2} \mathrm{H}_{2} \Rightarrow$ products pathway.

Finally, analysis of the chemical flux shows that acetaldehyde is formed by the radical recombination reaction of ${ }^{\circ} \mathrm{CH}_{3}+$ $\mathrm{H} \cdot \mathrm{CO} \leftrightarrows \mathrm{CH}_{3} \mathrm{CHO}$. We have identified that in order to gain agreement with the trace species measured in such a radical rich environment as that of the present study, it is necessary to pay close attention to radical-radical recombination reactions and the subsequent reactions of the resulting species. Moreover though not detected in experiment, the model predicts the formation of measurable quantities ( $>40 \mathrm{ppm}$ ) of formic acid, hydrogen peroxide, ethane, ketene and dimethyl ether through other, sometimes ill characterized, recombination reactions. As methyl and formyl radical recombination and other such reactions are described at the high-pressure limit rate constant, a pressure dependent treatment for these reactions would certainly improve model predictions.

\section{Conclusions}

The high-temperature oxidation of methyl formate has been studied in a low-pressure burner-stabilized laminar flame. Flame structures have been determined by the identification and quantification of reactant, intermediate and product species through flame-sampling molecular-beam synchrotron photoionization 
mass spectrometry (PIMS). These data are used to further test the predictive capabilities of a recently developed detailed kinetic model for methyl formate oxidation. The general agreement of model versus experiment indicates that the important processes of methyl formate oxidation are well understood and that the underlying fundamental methodology to model construction is sound, such that it may potentially be applied to describe the oxidation of larger methyl esters and other oxygenates.

Radical-radical recombination reactions are shown to be significant in the formation of a number of minor intermediate species such as ethylene, acetylene and acetaldehyde. This presents complications for kinetic modelers, as such recombination processes are often neglected in model construction for high pressure fuel dilute systems. Due to the extremely radical rich nature of these and other low-pressure flames, it is necessary to pay special attention to such reactions to accurately compute all of the trace species detected. In this study, we demonstrate the importance of this concept to ethylene formation through the formation of the larger esters, ethyl formate and methyl acetate, that are observed in the flame structure. The assumption that the rate constants of any recombination reactions are at their high-pressure limit values is certainly flawed for these experimental conditions. Accurate model replication of trace intermediate species will certainly require assessment of third body pressure effects.

Potential intrusive effects of the sampling cone on the flame structure are assessed by perturbation of the temperature profile employed in modeling computations. An assumed temperature uncertainty of $400 \mathrm{~K}$ is observed to translate experimental data by up to $2 \mathrm{~mm}$ along the $x$-coordinate and contributes uncertainties in computed mole fractions approaching a factor of two for some species. Significantly, these affects are not extreme enough to alter mechanistic conclusions of the kinetic model.

Previous chemical kinetic descriptions of methyl formate decomposition are tested against measured methanol profiles. Our previous description of methyl formate decomposition is observed to best reproduce the measured methanol concentrations. However reasonable adjustments in the pressure dependent parameters of the "ab initio" RRKM estimates of Metcalfe et al. [7] compute methanol profiles at the periphery of experimental uncertainties, such that more work is required to make definite conclusion on the kinetics of methyl formate decomposition.

\section{Acknowledgments}

The authors are grateful to Paul Fugazzi for expert technical assistance and for discussion with Dr. Marcos Chaos. This work is supported by the Division of Chemical Sciences, Geosciences, and Biosciences, Office of Basic Energy Sciences, US Department of Energy (USDOE), in part under grants DE-FG02-86ER13503 (S.D., F.L.D.) and DE-FG02-01ER15180 (T.A.C., B.Y., J.W.) and by the Chemical Sciences Division, US Army Research Office (T.A.C., B.Y., J.W.); S.D., F.L.D., B.Y., N.H. are also supported by the US Department of Energy, Office of Basic Energy Sciences under the Energy Frontier Research Center for Combustion Science (Grant No. DE-
SC0001198); Sandia is a multi-program laboratory operated by Sandia Corporation, a Lockheed Martin Company, for the National Nuclear Security Administration under contract DE-AC04-94AL85000. The Advanced Light Source is supported by the Director, Office of Science, Office of Basic Energy Sciences, Materials Sciences Division, of the USDOE under Contract No. DE-AC02-05CH11231 at the Lawrence Berkeley National Laboratory.

\section{Appendix A. Supplementary material}

Supplementary data associated with this article can be found, in the online version, at doi:10.1016/j.combustflame.2010.11.003.

\section{References}

[1] C.K. Westbrook, W.J. Pitz, P.R. Westmoreland, F.L. Dryer, M. Chaos, P. Oßwald, K. Kohse-Höinghaus, T.A. Cool, J. Wang, B. Yang, N. Hansen, T. Kasper, Proc. Combust. Inst. 32 (2009) 221-228.

[2] S. Dooley Ph. D. Thesis, National University of Ireland, Galway 2008.

[3] S. Dooley, M.P. Burke, M. Chaos, Y. Stein, F.L. Dryer, V.P. Zhukov, O. Finch, J.M. Simmie, H.J. Curran, Int. J. Chem. Kinet. 42 (2010) 527-529.

[4] J.-P. Lange, R. Price, P.M. Ayoub, J. Louis, L. Petrus, L. Clarke, H. Gosselink, Angew. Chem. Int. Ed. 49 (2010) 4479-4483.

[5] S.W. Benson, Thermochemical Kinetics, John Wiley and Sons, Inc., New York, 1976.

[6] J.S. Francisco, J. Am. Chem. Soc. 125 (2003) 10475-10480.

[7] W.K. Metcalfe, J.M. Simmie, H.J. Curran, J. Phys. Chem. A. 114 (2010) 54785484.

[8] T.A. Cool, K. Nakajima, T.A. Mostefaoui, F. Qi, A. McIlroy, P.R. Westmoreland, M.E. Law, L. Poisson, D.S. Peterka, M. Ahmed, J. Chem. Phys. 119 (2003) 83568365.

[9] N. Hansen, T.A. Cool, P.R. Westmoreland, K. Kohse-Höinghaus, Prog. Energy Combust. Sci. 35 (2009) 168-191.

[10] T.A. Cool, A. Mcllroy, F. Qi, P.R. Westmoreland, L. Poisson, D.S. Peterka, M. Ahmed, Rev. Sci. Instrum. 76 (2005) 094102.

[11] T.A. Cool, K. Nakajima, C.A. Taatjes, A. Mcllroy, P.R. Westmoreland, M.E. Law, A. Morel, Proc. Combust. Inst. 30 (2005) 1681-1688.

[12] T.A. Cool, J. Wang, N. Hansen, P.R. Westmoreland, F.L. Dryer, Z. Zhao, A. Kazakov, T. Kasper, K. Kohse-Höinghaus, Proc. Combust. Inst. 31 (2007) 285294.

[13] P. Oßwald, U. Struckmeier, T. Kasper, K. Kohse-Höinghaus, J. Wang, T.A. Cool, N. Hansen, P.R. Westmoreland, J. Phys. Chem. A. 111 (2007) 4093-4101.

[14] A. McIlroy, T.D. Hain, H.A. Michelsen, T.A. Cool, Proc. Combust. Inst 28 (2000) 1647-1653.

[15] R.J. Kee, G. Dixon-Lewis, J. Warnatz, M.E. Coltrin, J.A. Miller, Technical Report SAND86-8246, Sandia National Laboratories, Albuquerque, NM, 1986.

[16] D. Healy, H.J. Curran, J.M. Simmie, D.M. Kalitan, C.M. Zinner, A.B. Barrett, E.L. Petersen, G. Bourque, Combust. Flame 155 (2008) 441-448.

[17] J.C. Biordi, C.P. Lazzara, J.F. Papp, Combust. Flame 23 (1974) 73-82.

[18] R.J. Cattolica, S. Yoon, E.L. Knuth, Combust. Sci. Tech. 28 (1982) 225-239.

[19] U. Struckmeier, P. Oßwald, T. Kasper, L. Böhling, M. Heusing, M. Köhler, A. Brockhinke, K. Kohse-Höinghaus, Z. Phys. Chem. 223 (2009) 503-537.

[20] L.K. Huynh, K.C. Lin, A. Violi, J. Phys. Chem. A 112 (2008) 13470-13480.

[21] P.A. Glaude, W.J. Pitz, M.J. Thomson, Proc. Combust. Inst. 30 (2005) 1111-1118.

[22] A.Y. Chang, J.W. Bozzelli, A.M. Dean, Z. Phys. Chem. 214 (2000) 1533-1568.

[23] C. Sheng, J.W. Bozzelli, A.M. Dean, A.Y. Chang, J. Phys. Chem. A 106 (2002) 7276-7293.

[24] H. Hippler, J. Troe, H.J. Wendelken, J. Chem. Phys. 78 (1983) 6709-6717.

[25] G.P. Smith, D.M. Golden, M. Frenklach, N.W. Moriarty, B. Eiteneer, M. Goldenberg, C.T. Bowman, R.K. Hanson, S. Song, W.C. Gardiner Jr., V.V. Lissianski, Z. Qin. GRI-Mech 3.0. <http://www.me.berkeley.edu/gri_mech/>.

[26] H.J. Curran, P. Gaffuri, W.J. Pitz, C.K. Westbrook, Combust. Flame 114 (1998) 149-177.

[27] N. Hansen, J.A. Miller, T. Kasper, K. Kohse-Höinghaus, P.R. Westmoreland, J. Wang, T.A. Cool, Proc. Combust. Inst. 32 (2009) 623-630. 


\title{
Supplememtary Materials for
}

\section{An Experimental and Kinetic Modeling Study of Methyl Formate Low-Pressure Flames}

\author{
S. Dooley ${ }^{1 *}$, F.L. Dryer ${ }^{1}$, B. Yang ${ }^{2}$, J. Wang ${ }^{2}$, T. A. Cool ${ }^{2}$, T. Kasper ${ }^{3}$, N. Hansen ${ }^{3}$ \\ ${ }^{1}$ Department of Mechanical and Aerospace Engineering, Princeton University, Princeton, NJ 08544, USA \\ ${ }^{2}$ School of Applied and Engineering Physics, Cornell University, Ithaca, NY 14853, USA \\ ${ }^{3}$ Combustion Research Facility, Sandia National Laboratories, Livermore, CA 94551, USA
}

\section{Uncertainty analysis, C2 formation}

Dooley et al. employ,

$\mathrm{C} 2 \mathrm{H} 3+\mathrm{O} 2=\mathrm{HCO}+\mathrm{CH} 2 \mathrm{O}$

4.580E+16-1.39 1.015E+03 !FROM GRI MECH 3.0

$\mathrm{C} 2 \mathrm{H} 3+\mathrm{O} 2=\mathrm{HO} 2+\mathrm{C} 2 \mathrm{H} 2$

1.337E+06 1.61 -3.840E+02 !FROM GRI MECH 3.0

$\mathrm{C} 2 \mathrm{H} 3+\mathrm{O} 2=\mathrm{O}+\mathrm{CH} 2 \mathrm{CHO}$

The affect of this vinyl $+\mathrm{O} 2$ chemistry on computed $\mathrm{C} 2 \mathrm{H} 2 / \mathrm{C} 2 \mathrm{H} 4$ profiles has been tested by replacing this kinetic scheme with that suggested by Hansen et al. and Curran et al., respectively as below.

Hansen et al. employ,

$\begin{array}{lllll}\mathrm{C} 2 \mathrm{H} 3+\mathrm{O} 2=\mathrm{HCO}+\mathrm{CH} 2 \mathrm{O} & 9.33 \mathrm{E} 13 & -0.653 & 268.7 & \text { ! KLIPP. \& MILLER } \\ \mathrm{C} 2 \mathrm{H} 3+\mathrm{O} 2=\mathrm{H}+\mathrm{CO}+\mathrm{CH} 2 \mathrm{O} & 2.19 \mathrm{E} 14 & -0.653 & 268.7 & \text { ! KLIPP. \& MILLER } \\ \mathrm{C} 2 \mathrm{H} 3+\mathrm{O} 2=\mathrm{CH} 2 \mathrm{CHO}+\mathrm{O} & 7.52 \mathrm{E} 8 & 0.965 & -137.4 & \text { ! KLIPP.\& MILLER }\end{array}$

Curran et al. employ,

$\mathrm{C} 2 \mathrm{H} 3+\mathrm{O} 2<=>\mathrm{C} 2 \mathrm{H} 2+\mathrm{HO} 2$ 2.12E-06 6.0 9.48E03 !CURRAN NC7 COMBUST FLAME 2004 VERSION.

$\mathrm{C} 2 \mathrm{H} 3+\mathrm{O} 2<=>\mathrm{CH} 2 \mathrm{O}+\mathrm{HCO}$ 8.500E $+28-5.3126 .500 \mathrm{E}+03$ !CURRAN NC7 COMBUST FLAME 2004 VERSION.

$\mathrm{C} 2 \mathrm{H} 3+\mathrm{O} 2<=>\mathrm{CH} 2 \mathrm{CHO}+\mathrm{O}$ 5.500E+14 -0.611 5.260E+03 !CURRAN NC7 COMBUST FLAME 2004 VERSION. 